\title{
Academic Libraries in Transition: some leadership issues - a viewpoint
}

Robert Moropa

University of Pretoria, Pretoria, South Africa

Table of contents

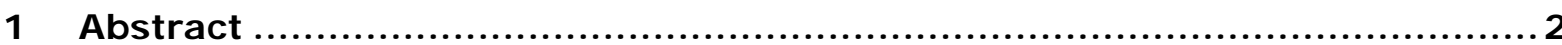

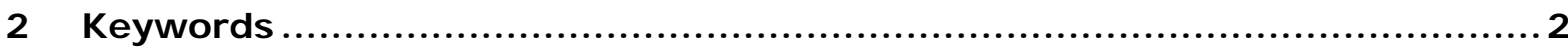

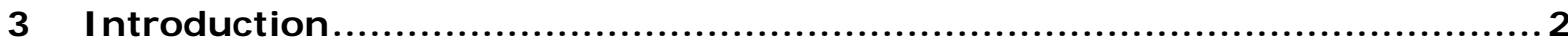

4 The environment of academic libraries .................................................. 3

5 Some of the causes of the decline of successful companies .........................5

6 Overcoming the negative attitudes and habits .......................................

7 How the University of Pretoria Library is combating being marginalised ..... 8

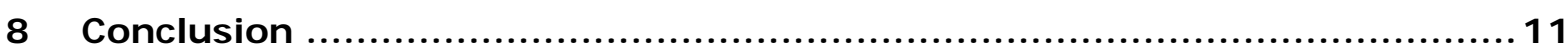

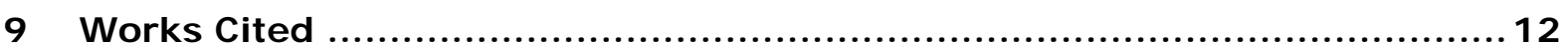




\section{Academic Libraries in Transition: some leadership issues - a viewpoint}

\section{Abstract}

Academic libraries, in general and more specifically in Africa, are at varying stages of decline: they are gradually being dislodged as top "go-to" places. Through this article it is suggested that leaders of academic libraries turn to the private sector to learn strategies through which this decline can be stopped or even reversed. The aim of this article is to facilitate that learning process by identifying and analysing the errors or mistakes committed by leaders of other organisations, especially those that were once regarded as successful. The literature that focuses on this phenomenon will be scanned with a view to learning more about once successful companies that failed. Factors such as arrogance, complacency and denial have been identified as some of the factors that contributed towards their failure. This article will conclude with a discussion of this experience at the University of Pretoria and the strategies applied to prevent it from being marginalized. The value of this article lies in the identification and suggestion of a practical method that leaders of academic libraries can employ in preventing or reversing the decline of their libraries

\section{Keywords}

- $\quad$ Decline

- $\quad$ Leaders

- Leadership

- Library

- University

- $\quad$ Strategy

\section{Introduction}

The survival of academic libraries is increasingly coming under threat. For instance academic libraries have been edged out of the top spot as the "go-to" place for learners and researchers by the convenience and immediacy of the Web (Wood, 2007, p. 3). Although academic libraries have and still are being referred to as the heart of the university it does appear that, in reality, they are being or have been dislodged from that position. The phrase "our library is the 
heart of the university" has become hollow. It does not carry as much weight as it did in the past.

There are several ways in which leaders of academic libraries can prevent their library from being marginalised or even reverse the trend, if that has already occurred. The approach proposed in this article is through learning from the mistakes made by managers or leaders of other organisations. In the report prepared by CLIR (Council on Library and Information Resources., 2008) a parallel is drawn between libraries and the U.S Postal Service, which states that:

Unless libraries take action, participants cautioned, they risk being left with responsibility for low-margin services that no one else ...wants to provide. An analogy is the U.S. Postal Service (USPS). Its innovative, high-margin services,... have been taken over by private firms, leaving the USPS largely with its lowestmargin-of-return function (Council on Library and Information Resources., 2008, p. 4)

The aim of this article is to facilitate this learning process by identifying and analysing the errors or mistakes committed by leaders of other organisations, especially those that were once regarded as being successful. It is hoped that through this vicarious learning process leaders of academic libraries will avoid committing similar mistakes or errors and take steps timeously to steer their libraries in the right direction. The relevant literature will be scanned with a view to learning more about such companies.

It needs to be pointed out, however, there exists significant differences between academic libraries and private sector companies. Firstly, academic libraries are not autonomous institutions, such as IBM. Secondly, academic library leaders do not have the enormous power and authority that leaders of private sector companies have. It is, therefore, conceivable that factors that may have led to the failure of private sector organisations may not necessarily be a threat for academic libraries to the same degree. It can, though, be argued that lessons from the for-profit sector do hold some benefit for leaders of academic libraries. Avoiding the negative habits of the leaders of organisations that failed will place leaders of academic libraries in a stronger position to combat the decline of their organisations, as will be discussed later.

This article concludes with a discussion of the experience at the University of Pretoria and the strategies applied to prevent the library there from being marginalised.

\section{The environment of academic libraries}

Academic libraries, like their parent organisations (i.e. universities) exist in a dynamic environment. Changes in legislation, technological developments, the fluctuating state of the economy, currency fluctuations (especially in Africa) have an impact upon them. In reality the library's situation is even more volatile than that of the university, since it stands with one leg in the education sector and the other in the ICT sector; and it is largely dependent on the situation/ 
status of the university: if the university goes down, the library certainly will be dragged with it.

Kargbo, regarding the African academic libraries, states:

African university libraries are at a crucial stage of their evolution. There is pressure and competition created by these technological innovations, networks, user demands, and the increased demand or information requirements of the new age. These changes demand new missions, goals, objectives, organization structure and managerial skills. African university libraries are therefore compelled to re-examine their very existence in academia and justify the need for their services. (Kargbo, 2002, p. 411)

African academic libraries share these environmental changes or evolution with the broader community of academic libraries. However, the African academic libraries are also faced with unique challenges that make it even more difficult for them to respond appropriately to the evolving environment described above. Kargbo refers to these additional challenges as follows:

African universities are compounded by huge problems, which range from lack of funds, leading to shortage of book and nonbook material in the library, inadequate lack of basic services such as water, electricity, reliable communication systems, inadequate infrastructure, maintenance and technical facilities, to low staff salaries and a brain drain (Kargbo, 2002, p. 412).

The situation in Africa is further worsened by the information divide which has resulted in the computer/information skills of users being a major complicating challenge; those skills range from non-existent to highly developed - with the poorly developed group forming the bigger proportion - and academic libraries in Africa have to cater for the entire spectrum.

It should be mentioned, however, that the situation among universities in South Africa as well as the Universities of Botswana and Namibia, has not yet deteriorated to the level described by Kargbo. Generally speaking universities in South Africa are, in varying degrees, still relatively well resourced compared to some of the academic libraries in the rest of Africa.

The position of libraries in Africa is certainly under threat. Wood et al. state that academic libraries have been under threat since the dawn of the twenty-first century. That threat is characterised by an inexorable decline in purchasing power, in some cases diminished influence on campus and the erosion of their status as sole provider of information (2007, p. 4)

That decline can be reversed. The author agrees with Wood et al. when they emphasise the need for leaders who will rescue their libraries from being "wedded to the status quo" but transform them to being "a vital partner and preferably a leader in the campus learning community" (Wood, 2007, p. 92). They correctly caution that failure to provide such transforming and transitioning leadership will result in academic libraries being “.... relegated to a poorly funded and marginalized artefact of past relevance" (Wood, 2007, p. 92). 


\section{Some of the causes of the decline of successful companies}

The additional challenge that leaders of academic libraries are faced with is that the decline of academic libraries is slow. In other words it is not as dramatic as that of the organisations in the private sector. The decline within the academic library sector is taking place stealthily. It is not characterised by a dramatic fall of profits and share prices.

The dramatic nature of the decline of organisations in the private sector is advantageous in the sense that it causes a crisis that jolts all the relevant stakeholders into taking appropriate action to halt the process. This therefore presents us with learning opportunities. Leaders of academic libraries can learn, among others, important lessons regarding the causes of the decline, how the decline can be detected and reversed.

Few successful companies stay equally successful year after year. Examples of such companies are those listed at the top of the stock market in 1907, 1957 and 2007, and one will see very few repeaters. Why is this? (Adams, 2007). Another equally important question that Collins asks is: “...how would you know?"; meaning how will you know that your company is on the decline. He poses that question after making the following sobering statement:

When you are at the top of the world,...the most successful company in your industry, the best player in your game, your very power and success might cover up the fact that you're already on the path to decline. So, how would you know? (Author's emphasis) (Collins, 2009, p. 2)

Academic libraries, as the heart of their respective university (or as the top "go-to" places), may be in the process of being replaced. How would we know for sure (or convince all the academic library staff members) that this is happening or that the decline has started? Most importantly, how should we mitigate that risk? Those are the lessons that organisations in the private sector can teach us.

There are several factors that researchers working in this area have identified as having contributed to or led to the downfall of successful organisations. Arrogance, it would seem, a leading reason for successful companies failing. Christensen, Finkelstein, Collins, and Sheth have written extensively in their respective books of how arrogance on the part of leaders of organisations contributes to the downfall of successful organisations. Christensen uses Sears Roebuck, IBM, Xerox and other companies as examples of companies which, at some stage, were highly regarded in their respective industry. Christensen states the following about Sears:

It is striking to note that Sears received its accolades at exactly the time - in the mid-1960s - when it was ignoring the rise of discount retailing and home centers, the lower-cost formats for 
marketing name-brand hard goods that ultimately stripped Sears of its core franchise (Christensen, 1997, p. X).

Arrogant leaders of successful organisations reach a point where they regard success “...virtually as an entitlement, and they lose sight of the true underlying factors that created success in the first place". (Collins, 2009, p. 21)

Finkelstein (2003, p. 214) has put forward seven habits of unsuccessful CEO's. It is interesting to note that one of these habits is one that could be referred to as pride (which is the opposite of humility). He says that those CEO's "..see themselves and their companies as dominating their environment". He says they suffer from what he calls "the illusion of personal pre-eminence". That is a tendency adopted by those CEO's who believe that they are personally able to control the things that will determine their company's success or failure. Finkelstein describes how this tendency contributes to the demise of these CEO's as follows:

Rather than scrambling to keep track of changing conditions, the CEO's who succumb to this illusion believe that they can create the conditions under which they and their company will operate. What's more, they believe that they can do it by their own personal genius and force of personality... As far as they're concerned, everyone else in the company is there to carry out their personal conception of what the company should be (Finkelstein, 2003, p. 215)

That tendency seems to blind CEO's to the changes that are taking place around them. Which results in those CEO's failing to effect necessary changes and adjustments that are required within their companies to survive and thrive in the changed or new environment.

Complacency has been identified as another of the attitudes adopted by leaders of successful organisations that may go into decline or are already in decline. Sheth defines complacency as “...the sense of security and comfort that derives from the belief that the success you've had in the past will continue indefinitely" (Sheth, 2007, p. 75). That attitude has a tendency to kill creativity within an organisation. It also kills the motivation for staff to adopt change. Complacent staff members within an organisation tend to want to maintain the status quo, especially when the organisation is successful or doing well.

Denial has, according to Sheth and other researchers, contributed in the decline of successful organisations. According to Sheth the following dictionary's primary definition of denial is accurate: "'disbelief in the existence of reality of a thing or refusal to recognise or acknowledge that reality"' (Sheth, 2007, p. 19). This is that bizarre state of mind that causes successful companies to think because they are successful now they will be successful forever (Adams, 2007, p. 24).

It does appear that denial played a role in causing Switzerland to lose its dominance in the watch-making market in the late 1970s. Prior to that period their market share in the world was $65 \%$ and they made more than $80 \%$ of the profits (Barker, 1993, p. 16). Switzerland lost their dominance of that market to the Japanese, who put the electronic quartz watch onto the market. Although it 
was the Swiss watch researchers that invented the quartz watch, the successful Swiss watch manufacturers rejected it when it was presented to them in 1967 because they were convinced that "It couldn't possibly be the watch of the future" (Barker, 1993, p. 17). They denied the reality of the new technology which went on to cause a major decline in this industry in Switzerland.

Some librarians tend to adopt the same approach when confronted by the reality of the new technologies, such as the Internet, Google and Web 2.0 tools. Their stance tends to be that the library is superior or better than those new technologies or they look for faults with those technologies. We are now faced with the situation where the growth in Google popularity seems to be translating into a decline in the use of the library (Hawkins, 2009, p. 27). The smart move was adopted by those librarians who registered their link resolvers with Google. "This way, users can continue discovery through the federated search connection" (Hawkins, 2009, p. 28).

For a long time academic libraries were servicing a captive audience and their relevance and importance were not in doubt. Students, staff and researchers had nowhere else to go but to the library for sources of information. According to Euster (1995, p. 2), since the 1920's academic libraries in the USA were highly regarded. It is highly likely that this was the case in other countries. This favourable situation for academic libraries may have caused some library leaders to be complacent or even arrogant. They may have thought that that favourable situation for academic libraries would last forever.

It is easy, probably with the benefit of hind sight, to see how an arrogant and complacent leader can deny the developments that are taking place around him/her. Arrogant leaders tend to regard their organisations as setting the standard for their industry. Acknowledging developments emanating outside their organisations is contrary to their belief that they cannot be outdone by someone else, since they are the leaders.

\section{Overcoming the negative attitudes and habits}

Destructive habits or attitudes such as the ones mentioned above can be overcome. Leaders of academic libraries will do well to work hard at overcoming those attitudes within their organisation, to prevent them from declining. Collins strongly maintains that "the path to recovery lies first and foremost in returning to sound management practices and rigorous strategic thinking" (Collins, 2009, p. 117). That underlines the fact that the leader is responsible for personally tackling those habits and ensuring that they do not drag her/his organisation down.

Sheth suggests that the leader should break the habit of arrogance by 'opening the doors and windows, to let some light shine in.' He goes on to say that "the leader must change the culture to one of looking, listening, and learning... from the experience of those outside the company" (Sheth, 2007, p. 70). Staff should be well informed of new developments happening outside the organization on an ongoing basis and should be given tasks that will constantly challenge them. That action will also help to prevent complacency from setting in. 
Leaders of academic libraries can cure arrogance and complacency by adopting the same attitude as Darwin E Smith. Collins quotes Smith who, when reflecting on his exceptional performance, stated: "I never stopped trying to become qualified for the job" (Collins, 2001, p. 20). The job that Smith was referring to was that of being the CEO of Kimberly-Clark, the company that he made great. Leaders of academic libraries should never stop trying hard to demonstrate that their libraries qualify to be the heart of their respective institution. That attitude will open their mind to opportunities and avenues that they can utilise to demonstrate to their university community the worth and relevance of their library.

An academic library leader should get the library staff into the habit of scrutinising new technologies, and trends, staying in touch with the attitudes, needs and styles of its user population through doing regular user surveys and then acting on the result of those surveys. Through adopting this approach academic libraries will remain informed of the developing trends. Such action will make denial unnecessary.

\section{How the University of Pretoria Library is combating being marginalised}

Having been established in 1908, University of Pretoria is 102 years old. It is one of the leading research universities in South Africa. In 1996, University of Pretoria became recognised as being the university with the highest research output in South Africa and has managed to maintain that status. It currently serves more than 40000 students. The University comprises six campuses and a number of other sites of operation, such as the Pretoria Academic Hospital. Central administration is located on the Hatfield campus. University of Pretoria offers more than 1800 academic programmes in nine faculties and a business school. The faculties comprise 140 departments and 85 centres, institutes and bureaus (University of Pretoria, 2008).

University of Pretoria Library Services (UPLS), which has 175 permanent posts and 65 contract posts, is guided by its mandate and vision. The UPLS mandate states: The Library is responsible for the management of academic information and knowledge, and for leading the University in information and knowledge innovation. The vision of the UPLS is as follows: We strive to be a world-class $21^{\text {st }}$ century academic research library enabling the University of Pretoria to be an internationally recognized research university. This vision is inspired by the main strategic objective of the University, namely: to become an internationally recognised South African teaching and research university.

A process of self-evaluation, which commenced in 2006 in preparation for the HEQC (Higher Education Quality Committee) Audit that was conducted in 2007, allowed the Library to assess whether it was fit for its present and future purpose. The Audit Report released in 2008 affirmed that it was when it commended the UP Library Services (UPLS) for being efficiently managed and well-resourced (Council on Higher Education, 2008). That pronouncement endorses the efficacy of the Library's 5-year Strategic Plan (2005-2010), which is reviewed and assessed on an annual basis. Through implementing that 
strategic plan the Library has been able to embark on initiatives that have placed the UPLS in the forefront of developments in the LIS sector.

The library leaders used the strategic plan to demonstrate to the University leadership that the Library was prepared to support the University at all levels to achieve its goals.

Applying the strategic plan as framework, the Library formulated an einformation strategy in 2006. The aim of that strategy was to make optimum use of the Web 2.0 tools in supporting teaching, learning and research. As part of that strategy the Library has established the institutional repository known as UPSpace. In 2004/5 the UP Library was among the first academic libraries, in South Africa, to register its link resolver with Google Scholar.

The UPLS, in line with its mandate and vision, has defined itself as a major and significant role player within the University of Pretoria. As a result it has initiated and led a number of significant university-wide projects and programmes. An example is the Electronic Thesis and Dissertation (UPETD) project. That project, which entailed switching away from printed $M$ and $D$ theses and dissertations to the electronic format, was led by the Library. The UPLS took the responsibility of establishing and running a digital institutional repository known as UPSpace. In 2009 the UPLS initiated and led the process that culminated in the adoption by the University of the Open Access Mandate.

Since the mid-1990s the UPLS also implemented the Quality Assurance programmes and processes. Some of the programmes include users and staff members' surveys. Examples of these are:

- SERVQUAL - implemented in 2001

- In-house regular client surveys - implemented as from 2004

- LibQUAL - implemented in 2005 and 2009

- Investors In People evaluation - implemented in 2009.

Feedback received from those surveys is taken seriously and is fed into the strategic planning and implementation processes and programmes. Those surveys enable the Library to keep in touch with the needs of its users, staff members and other stakeholders within the University.

At present the UP Library is in a fortunate position in that the members of the University of Pretoria Executive, members of the research community, academic staff members and students hold the Library in high esteem. That sentiment is gleaned from the results of the surveys that the Library conducts on a regular basis. The following are examples of some of the comments made by the members of the University of Pretoria community during the two LibQUAL survey that UPLS has been involved in:

- $\quad$ LibQUAL Survey of 2005

o "The service is always excellent, actually unbelievably good."

o "I love the way it has improved and still improving. It clearly shows that the University of Pretoria and the library staff care a lot about the 
students and the services they render to us and for that thanks a lot and keep up the good work."

- $\quad$ LibQUAL Survey of 2009

- "This library service is on par with the best in the world: client focused and in the forefront of the latest developments. With relatively limited resources, but thanks to the wonderfully devoted staff exceptional service is the norm."

o "The best library in the world! Outstanding staff, always enthusiastic and helpful. Thank you very much for your support."

Two of the biggest sustainability strengths for UPLS are: (a) that the Library leadership has managed to embed UPLS very well into the fabric of the university, largely on account of being pro-active and aligned with the university on all levels, leading, inter alia, to the Library's relatively healthy financial position, and (b) that the Library has adopted a participative and shared leadership approach with good effect resulting in leadership depth. This approach may have minimised the chances of arrogance developing within its leadership. The reason for this is that the successes of the organisation are as the result of a team effort.

The organisational structure below shows the areas of responsibility of each of the members of the leadership team or the executive of UPLS. Each member of the team takes ownership and leadership of their assigned area of responsibility within the framework of the strategic plan. 


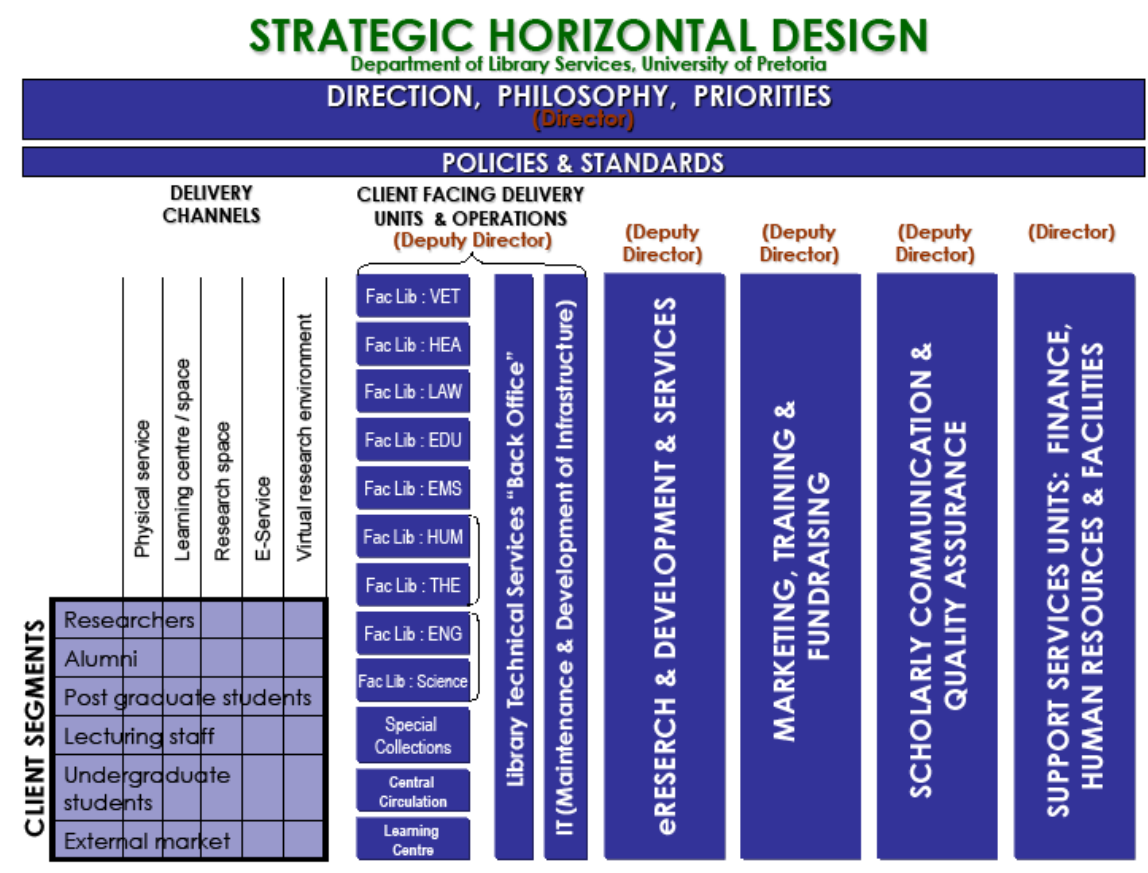

\section{Conclusion}

There seems to be an agreement among the researchers of failed companies that the leaders of these companies played a role in the downfall or near-downfall of those companies. Failure of an organisation can be attributed to a number of factors, such as circumstances beyond the leader's control, unions, lack of resources, other managers or employees etc. It would appear that most of the researchers apportion the bigger slice of the blame for the failure of the companies they have studied to their leadership. Sheth points out that companies, as they rise to excellence, often unwittingly develop self-destructive habits that eventually undermine their success (2007, p. 2). Finkelstein (2003, p. 2) puts the blame for business failure on the people who create, manage and lead the company.

Finkelstein goes on to say that leaders should not look for easy answers for the decline of their organisation. Leaders tend to blame others or circumstances for their failure instead of focusing on the real causes of failure and dealing with them. For instance, it is easy for the leaders of academic libraries to blame the managers of the university in which their library is located, lack of funding etc. While it would be incorrect not to acknowledge the fact that those and other factors can contribute to the decline of an organisation, it is important to also acknowledge and accept that the leader of an organization has also contributed in the decline of the company of which he/she is/was a leader. It is only after accepting this responsibility that a leader can be in a position to take decisive action to reverse the decline.

A challenge that leaders of academic libraries face is that of balancing or maintaining a balance between the present (i.e. delivering services to current users) and the future (designing appropriate services and products for the client of the future). Focusing only on the present is disastrous for any organisation (as has happened in the past) since the dynamic environment will render it 
irrelevant. Focusing only on the future will result in a disconnect occurring between the organization and its current major or significant stakeholders. Such an eventuality will threaten the sustainability of the organisation. One of the major tasks, therefore, of an academic library leader is to ensure that his/her organisation maintains a healthy balance between focusing on the present and the future.

\section{Works Cited}

Adams, J. (2007, Septembert). Why do good companies fail? Supply house times , pp. 24-25.

Barker, J. A. (1993). Paradigms: the business of discovering the future. New York: Harper.

Christensen, C. M. (1997). The innovator's dilemma: when new tecnologies cause great firms to fail. Boston: Harvard business school press.

Collins, J. (2001). Good to great: why some companies make the leap...and others don't. London: Random house.

Collins, J. (2009). How the mighty fall and why some companies never give in. London: Random House.

Council on Higher Education. (2008). Audit report on the University of Pretoria: report of the HEQC to the University of Pretoria. Pretoria.

Council on Library and Information Resources. (2008). No brief candle: reconceiving research libraries for the 21st century. Washington D. C: CLIR.

Euster, J. R. (1995). The Academic Library: Its place and Role in the Institution. In G. B. McCabe, Academic Libraries: their reationale and role in American higher education (pp. 1 - 13). Connecticut: Greenwood.

Finkelstein, S. (2003). Why smart executives fail: and what you can learn from their mistakes. New York: Penguin.

Hawkins, D. T. (2009). Google meets publishers and librarians. Information Today , 27-29.

Kargbo, J. A. (2002). African universities and the challenge of knowledge creation and application in the information age. Library review , 411-416.

Kotter, J. P. (1996). Leading change. Boston: Harvard business school press.

Penzhorn, C. \& Pienaar, H. (2009). The use of social network tools for innovative service delivery at the University of Pretoria Library. Innovation , 66-77.

Sheth, J. N. (2007). The self-destructive habits of good companies: and how to break them. New Jersey: Wharton.

University of Pretoria. (2008). About the University of Pretoria. Retrieved March 01, 2010, from University of Pretoria: http://web.up.ac.za/default.asp?ipkCategoryID=1 
University of Pretoria Library Services. (2009). Annual Report - 2008. Pretoria.

Wood, E. e. (2007). Beyond survival: managing academic libraries in transtion. . Westport: Libraries Unlimited. 